\title{
The Effect of Financial Performance on Human Development Index of Districts and Cities Governments in North Maluku Province
}

\author{
Susilo Darma Satriawan, Abdul Hadi Sirat and Suwito \\ Study Program of Management, Concentration of Local Financial Management, Khairun University, Ternate
}

\begin{abstract}
The research aims to analyze the effect the financial performance on Human Development Index (HDI) of local government in North Maluku Province. The financial performance used are decentralization, independence, and effectiveness ratios. This study uses quantitative research with research subjects of districts and cities in North Maluku Province. This study involves 10 regencies/cities as the population of North Maluku Province during 2015 - 2019. The research population used was 50 samples for five years duration. The research analysis is multiple regression models. The results show that decentralization, independence and effectiveness ratio have significant and positive effect on human development index. Higher decentralization, independence and effectiveness will increase the Human Development Index. Fiscal decentralization as mandated in law has been implemented by district and city governments in North Maluku Province. The decentralization and independence ratios show a positive relationship with community based on by Human Development Index. The effectiveness ratio supports the other two ratios in efforts of District and City governments to increase the Local income as an important factor for decentralization and local independence.
\end{abstract}

Keywords: Financial Performance, Human Development Index

DOI: $10.7176 /$ RJFA/12-18-09

Publication date:September $30^{\text {th }} 2021$

\section{INTRODUCTION}

Development has a broad meaning. It is interpreted as a process to create community welfare in countries development. Prosperity is a condition in which the people are prosperous, healthy and able to fulfill their basic life capacities. The development should be able to broaden people's choices to achieve their welfare. However, current problem is the development achievements in various regions are partially varied. There is an area that has succeeded to develop and other areas have not been able to develop properly.

The wide area, different geographical conditions and diverse culture of society are developments challenges in Indonesia. Therefore, government implemented a policy of local autonomy and fiscal decentralization as regulated in Law Number 23 of 2014 on Local government which was later refined by Law Number 9 of 2015, as well as Law Number 33 of 2004 on Financial Balance between the Central and Local Governments. Local governments use this policy to determine development priorities.

One development priority realized by local governments to improve the community welfare is the provision of public services. The provision of public services is a government intervention in an effort to meet the community needs (Mouw, 2013). The people welfare improvement can be proxied by higher Human Development Index (HDI). Amalia and Purbadharmaja (2014) stated that success indicators of local autonomy are the improvement in public services and welfare, progressive democratic life, a sense of justice, equity, as well as a vertical harmonious relationship between the central and local Governments and horizontal relations between regions. It shows the government performance increase. The measurement to analyze the local governments performance in their finances management is financial ratio analysis to the determination and implementation of Local Expenditure and Expenditure Budget (Halim, 2007).

The performance analysis of district/municipal financial management in North Maluku Province will produce important information to make policies for local finances management. District/City Governments in North Maluku Province should improve the local apparatus organization in local revenue management systems by refreshing local apparatus organization to collect local revenue management and to redistribute wisely. Local revenue is still low compared to other regions due to lack of human resources to manage the local revenue, targets setting and local revenue unprofessional and weak supervision with high level of corruption.

Several related research results show that local financial performance can be used as a basis to measure the success of local governments in local autonomy implementation. Muhajirin (2019) stated that local financial performance has an effect on people's welfare. Berliani (2016) stated that financial performance affect on people welfare. Performance improvement of local government financial is followed by HDI improvement.

Sutaryo (2015) showed that decentralization ratio has a positive effect on HDI and independence ratio has a negative effect on human development index. However, Bharanti (2019) showed that decentralization ratio has no effect on HDI. Amalia and Purbadh Armaja (2014) showed that Local financial independence and 
compatibility of expenditure allocations have a positive effect on HDI in sense that higher Local financial independence and compatibility of expenditure allocations will improve the human development index. Berliani (2016) stated that effectiveness ratio had an effect on HDI. Adversely, Harliyani and Haryadi (2016) stated that effectiveness ratio had no effect on human development index. Based on the phenomenon and the research gap, this study aims to examine the Effect of Financial Performance on Human Development Index of District and City Governments in North Maluku Province". The financial performance uses indicators of decentralization, independence and effectiveness ratios.

\section{LITERATURE REVIEW}

Financial performance

Performance can be interpreted as a measured activity of an entity during a certain period as part of measurement of a job success (Kasmir, 2015). The performance shows the plan achievement. Good performance is showed by achievement exceeds the plan. The Presidential Instruction No. 7/1999 on accountability for performance of government agencies performance is a description of the achievement level of an activity/program/policy implementation to achieve the goals, mission, and vision of an organization. The Regulation of Minister of Home Affairs Number 13 of 2006 states that "performance is the output or result of activities or programs achievement in relation with budgets usage with measured quantity and quality".

Financial performance is analyzed by various tools to assess the past performance to obtain a near reality financial position and potential future performance. The financial performance of local government is a level of field work achievement of local finance which includes regional revenues and expenditures. The calculation of this achievement is done by financial indicators determined in accordance with statutory provisions for a certain period or through a certain policy. Good local financial performance requires the ability of local governments to manage all local financial resources with aim to meet all community needs and reducing dependence on central government.

Performance measurement is defined as a financial or non-financial system of a work done or achievement from an activity, a process, or an organization. Mahmudi (2011) stated that, performance measurement shows the results of an activity/policy implementation, but performance measurement does not analyze the reasons or identify the changes needed to achieve the activity/policy objectives.

Financial performance of local government is a field work achievement of local finance which includes the budget and local revenue realization using financial indicators determined through a policy or statutory provision in one budget period. The activities are done by government and related the infrastructure construction and public service should be able fulfill local finance responsibility. The public can assess the local governments performance. Measurements of finance performance of local governments are often used to assess local financial management.

\section{Decentralization Ratio}

The decentralization ratio is the ability to increase local revenue of local government to finance the construction (Mahmudi, 2010). This ratio is calculated by comparing the amount of local revenue and local revenue. Better contribution of local revenue will increase local governments capacity to implement the decentralization.

\section{Independence Ratio}

Local financial independence shows the ability of local governments to finance their government activities. Local financial independence is shown by comparison between the amount of local revenue and local income. Local revenue plays an important role in regional financing. The local revenue should become the largest part of all regional revenues in mobilizing local government administration funds. An important actor in local financial capacity can be seen from local revenue.

\section{Effectiveness Ratio}

The level of effectiveness of local finance is used to measure effectiveness in realizing local government revenues and is the level of achievement of implementation of an activity or achievement achieved by local government.

\section{Human Development Index}

United Nations Development Program (UNDP) stated that human development is a process to enlarge choices for humans. The concept or definition of human development basically includes a very broad dimension of development. The human development concept should be analyzed and understood from human point of view, not only from economic growth. UNDP (1995) stated important premises in human development below.

1. Development must prioritize the population as the center of attention.

2. Development means to increase choices for people, not only to increase their incomes. Therefore, 
concept of human development must be centered on population as a whole, and not only on economic aspect.

3. Human development attention not only to increase the human skills but also the efforts to harness the human capabilities optimally.

4. Human development is supported by four main pillars, namely: productivity, equity, sustainability, and empowerment.

5. Human development becomes the basis to set the development goals and analyzing the options to achieve them.

The complete human development concept requires the improvement in the quality of life of population, both physically, mentally and spiritually. It is explicitly stated that development should focuses on human resources in line with economic growth. The physical and mental human resources development means the increase of population basic capacity which will then increase the opportunity to be able to participate in process of sustainable development. The Human Development Index (HDI) is intended to measure the impact of efforts to increase these basic abilities. It uses impact indicators as the basic component of its calculation, namely, life expectancy at birth, educational attainment as measured by number of years of school expectation and average length of schooling, as well as consumption expenditure. The HDI value of a country or region shows the country or region implementation to the specified target, namely a life expectancy of 85 years, basic education for all levels of society (without exception), and levels of expenditure and consumption that have reached a decent standard of living.

UNDP has published a human resource development report in a quantitative measure called the Human Development Index (HDI). HDI is a measuring tool for human resource development that formulated constantly. It will never capture a perfect picture of human resource development. UNDP mentioned that indicators to measure the HDI dimensions below.

1. A long and healthy life, it is measured by life expectancy at birth variable.

2. Being knowledgeable, it is measured by two indicators, namely expected years of schooling and mean years of schooling.

3. Having a decent standard of living, it is measured by a macro basis through Gross National Product (GNP) per capita GNI.

\subsection{RESEARCH FRAMEWORK}

Above description shows the theoretical basis and previous studies. Researchers will examine the effect of decentralization, independence and effectiveness ratios on human development index. The research framework is shown in figure 1.

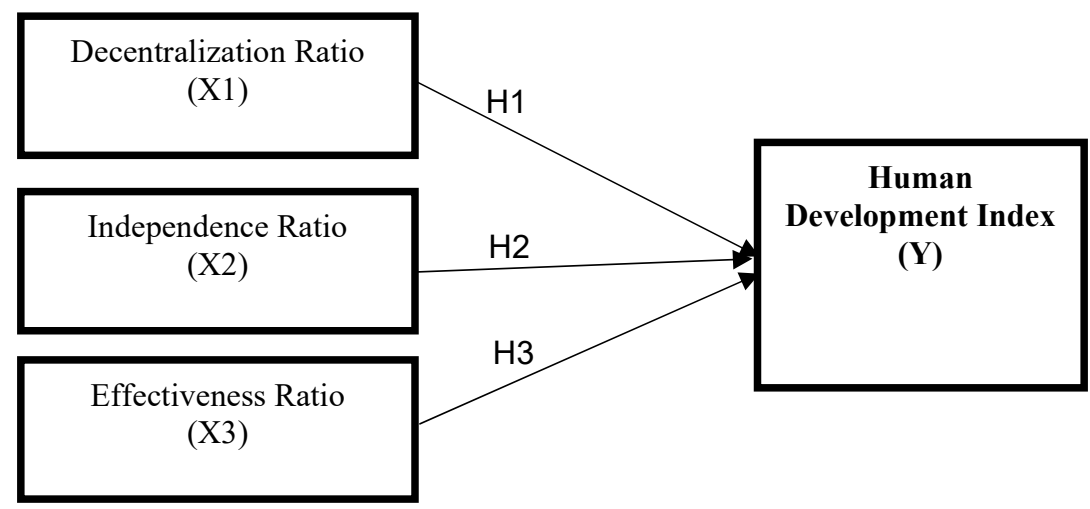

Figure 1. Research Framework

\subsection{Hypothesis Development}

The Effect of Decentralization Ratio on Human Development Index

The autonomous local government has the authority to regulate and managing the interests of local communities based on aspirations communities (Apriana and Suryanto 2010). The decentralization level shows the ability of local governments efforts to increase local revenue to finance the activities and development. The decentralization level can be used to measure by independence level between the central government and local governments (Mahmudi, 2007). Setyowati and Suparwati (2012) showed that local revenue has a significant effect on HDI, where local revenue is the main factor in assessing the decentralization ratio. Sutaryo (2015) 
showed that decentralization ratio has a significant effect on Human Development Index (HDI). Based on above description, hypothesis 1 is presented below.

H1: The decentralization ratio has a significant effect on human development index.

The Effect of Independence Ratio on Human Development Index

Local financial independence describes the region ability to become independent in the financing activities. In other words, this ratio can describe dependence level on external resources. Based on theory of fiscal federalism for fiscal decentralization implementation in regions, local governments should regulate and manage their own government. The government success will have an impact on better economy. This will continue to have an impact on quality of humans or society in region and the HDI in the region will also increase (Ardi, 2018). Amalia and Purbadharmaja (2014) showed that independence ratio has a significant effect on human development index. The independence ratio has a positive impact on community welfare. Based on description above, hypothesis 2 is presented below.

$\mathrm{H} 2$ : The independence ratio has a significant effect on human development index.

\section{Effect of Effectiveness Ratio on Human Development Index}

Local governments have the right and obligation to regulate and manage their own government affairs in local development to increase the effectiveness of government administration (Saiful, 2011). The local revenue effectiveness ratio shows the ability of local governments to realize local revenue revenues in accordance with the budget. Local governments ability to manage local revenue effectively should have adequate resources to do their duties in public services, especially related to education, health, and other fields that affect people's purchasing power parity as well as being an indicator of human development index. Berliani's research (2016) showed that local financial performance has a significant effect on people welfare. The financial performance indicators include the ratio of local financial effectiveness. The effectiveness ratio positively affect on humans welfare at the region. Based on description above, hypothesis 3 is presented below.

H3. The effectiveness ratio has a significant effect on human development index

\section{RESEARCH METHODS}

This research uses quantitative research (Iskandar, 2013). The design of this study analyzes the affecting (independent) variables of decentralization, independence, and effectiveness ratios and affected (dependent) variable of human development index.

This research is located in North Maluku Province. It includes district /city governments throughout North Maluku Province which has financial report data and calculations of HDI in 2015 to 2019. This research was conducted in 3 months, namely October to December 2020.

This study population is the local government in North Maluku which consists of all districts/cities in North Maluku Province. The samples are the entire population. The number of districts and cities in North Maluku Province is 10 districts/cities. It uses census sampling where the samples are all 10 districts/cities in North Maluku.

This study uses secondary data, ie information obtained from other party (Sekaran, 2016). The data needed in this study are the local government financial reports and HDI of districts/cities in North Maluku Province. The data is obtained from financial reports published by each district/city and HDI calculations published on website of Central Statistics Agency (BPS).

The data analysis method is multiple regression analysis. Classical assumption tests that must be met include tests of normality, multicollinearity, autocorrelation and heteroscedasticity tests.

\section{RESEARCH RESULTS AND DISCUSSION}

North Maluku Province was established in 1999 based on Law No. 46/1999. North Maluku Province consists of 2 cities and 8 regencies. Ternate and Tidore Islands Cities are 2 cities in North Maluku Province. The districts in North Maluku Province include Morotai Island, North Halmahera, West Halmahera, Central Halmahera, East Halmahera, South Halmahera, Sula Islands, and Taliabu Island Districts.

\section{Data Analysis Results}

The data analysis results consist of three parts, namely descriptive statistics, assumption testing and hypothesis testing with multiple linear regression. Descriptive statistics are used to provide an overview of each variable study. The descriptive statistics present of minimum, maximum, average, and standard deviation values of each variable. The results of descriptive statistics are presented in table 1. 
Table 1. Descriptive Statistics

\begin{tabular}{|l|r|r|r|r|}
\hline \multicolumn{1}{|c|}{ Variable } & Minimum & Maximum & \multicolumn{1}{c|}{ Mean } & \multicolumn{1}{c|}{ Std. Deviation } \\
\hline Human development index & 0.58 & 0.80 & 0.6586 & 0.05986 \\
\hline Decentralization ratio & 0.01 & 0.17 & 0.0504 & 0.03779 \\
\hline Independence ratio & 0.00 & 0.13 & 0.0494 & 0.03407 \\
\hline Effectiveness Ratio & 0.08 & 1.42 & 0.7112 & 0.28457 \\
\hline
\end{tabular}

Source: Primary data processed, 2021

Table 1 show that HDI variable has a minimum value of 0.58 with a maximum value of 0.80 and an average of 0.66 and a standard deviation of 0.06 . Furthermore, decentralization ratio has a minimum value of 0.01 , a maximum value of 0.17 , and an average of 0.05 and a standard deviation of 0.04 . The independence ratio variable has a minimum value of 0.00 , a maximum value of 0.13 , and a mean of 0.05 and a standard deviation of 0.03 . The effectiveness ratio variable has a minimum value of 0.08 , a maximum value of 1.42 , and a mean of 0.71 and a standard deviation of 0.28 .

Classical assumption test includes normality, multicollinearity, autocorrelation and heteroscedasticity tests. The results of normality test show that confounding variable or residual has a normal distribution because it has a significance value greater than 0.05 (Ghozali, 2013). It means that the data has normal distribution.

The multicollinearity test examines a correlation between the independent variables in regression model. The analysis results show that all variables are independent from multicollinearity (nonmulticollinearity). This is evidenced by all variables having tolerance values $>0.1$ and VIF $<10$ (Ghozali, 2013).

The autocorrelation test examines a correlation between the error or disturbance of $t$ period and confounding error of previous period (t-1) in linear regression model. The results of autocorrelation test show that Durbin Watson value of 1.827 is between $\mathrm{dU}$ to $4-\mathrm{dU}$. There is no autocorrelation in research model.

Heteroscedasticity test examines the inequality of variance from residual of one observation to another observation. The results of heteroscedasticity test show that all variables have a significance value $>0.05$. This means that all variables are independent from heteroscedasticity (non-heteroscedasticity).

\section{Multiple Linear Regression Test Results}

Hypothesis tests use multiple linear regressions. Multiple linear regression tests are used to determine the effect of more than one independent variable on one dependent variable. The test results are shown in table 2.

Table 2. Multiple Linear Regression Test Results

\begin{tabular}{|l|l|c|c|}
\hline \multicolumn{1}{|c|}{ Dependent Variable: Human development index } & t count & Sig. \\
\hline \multicolumn{1}{|c|}{ Variable } & \multicolumn{1}{|c|}{0.785} & 3,892 & 0.000 \\
\hline Decentralization ratio & \multicolumn{1}{|c|}{0.537} & 2,414 & 0.020 \\
\hline Independence ratio & 0.043 & 2,643 & 0,011 \\
\hline Effectiveness Ratio & \multicolumn{3}{|l}{} \\
\hline Constant & 0.562 & & \\
\hline Fcount; Sig & 53,$348 ; 0.000$ & \\
\hline Rsquare & 0.777 & & \\
\hline
\end{tabular}

Source: Primary Data Processed 2021

Constants are fixed numbers without the effect on other variables. Table 2 shows the constant value is 0.562 . This means that value of HDI will be 0.562 without being affected by variables of decentralization, independence, and effectiveness ratios. The significance of $F$ test (probability) is $0.000(p<0.05)$ and calculated $F$ value is 53.348 greater than the $\mathrm{F}$ table (2.81), it means that decentralization, independence, and effectiveness ratios simultaneously affect on HDI in province of North Maluku.

Table 2 shows that value of determination coefficient ( $R$ square) for multiple regressions between the independent variables and dependent variable is 0.777 . This shows that decentralization, independence, and effectiveness ratio simultaneously affect on HDI of District/City Government in North Maluku Province by $77.7 \%$ and remaining $22.3 \%$ of HDI are affected by other factors that are not investigated in this research.

First Hypothesis Test

Table 2 shows that decentralization ratio has a t-test significance of $0.000<0.05$ and a t-count value of $3.892>$ 2.009 ( $\mathrm{t}$-table). This means that decentralization ratio has a significant effect on HDI. Therefore, first hypothesis that decentralization ratio has a significant effect on HDI is accepted.

The research results consistent with previous of Harliyani and Haryadi (2016), Irviani and Kasmi (2017), Evlyn and Rahayu (2018), Sari and Riharjo (2020) and Hamimah and Zulkarnain (2020) that decentralization ratio positively affects on the HDI. This study results are inconsistent with previous research of Bharanti (2019) decentralization ratio had no effect on human development index. The success indicator of local autonomy is the ability to manage its economic resources rightly and ability to manage the Local revenue maximally. The ability 
to manage Local revenue will determine the success of Local government to achieve regional development goals. Higher local revenue will increase the funds to build public services for community. Public services fulfilled properly should increase the HDI.

\section{Second Hypothesis Test}

Table 2 shows that independence ratio has a t-test significance of $0.000<0.02$ and a t-count value of $2.414>$ 2.009 (t-table). This means that independence ratio has a significant effect on HDI. Therefore, second hypothesis that independence ratio has a significant effect on HDI is accepted.

This study results consistent with previous research of Amalia and Purbadharmaja (2014), Dewi and Sutrisna (2014), Swandewi (2014), Prasetyo (2015), Berliani (2016), Putry and Badrudin (2017), Irviani and Kasmi (2017), Iskandar and Subekan (2017), Dwiyandari and Badera (2018), Khairudin, Aminah and Redaputri (2020) that independence ratio has a significant effect on HDI. Adversely, this study results are inconsistent with previous research of Sari and Riharjo (2017), Astuti, Krisniawati, Zulkarnain, and Maifizar (2019), Bailusy (2019), Munfarida and Priyojadmiko (2020) that independence ratio has no effect on HDI. Local financial independence describes the region ability in financing activities in its region independently. The independence of each region is certainly different, according to regional resources that can be used to do regional activities (Mahmudi, 2011). Higher the independency ratio will increase the flexibility of local government to finance government expenditures whose benefits can be directly felt by community.

\section{Third Hypothesis Test}

Table 2 shows that effectiveness ratio has a t-test significance of $0.04<0.5$ and a t-count value of $2.643>2.009$ (t-table). This means that effectiveness ratio has a significant effect on HDI. Therefore, second hypothesis that effectiveness ratio has a significant effect on HDI is accepted.

This study results consistent with previous of Prasetyo (2015), Berliani (2016), Hamimah and Zulkarnain (2020) that effectiveness ratio had a positive and significant effect on HDI. Adversely, this study results are inconsistent with previous research of Harliyani and Haryadi (2016), Iskandar and Subekan (2017), Evlyn and Rahayu (2018), Astuti, Krisniawati, Zulkarnain, and Maifizar (2019), Khairudin, Aminah, and Redaputri (2020), Sari and Riharjo (2020), and Munfarida and Priyojadmiko (2020) that effectiveness ratio had no effect on HDI. The financial performance indicators include the ratio of local financial effectiveness where the effectiveness ratio contributes to society welfare in this region. Local governments that manage local revenue effectively should have sufficient resources to do their duties to provide public services, especially related to education, health, and other fields that affect people's purchasing power parity as well as being an indicator of HDI.

\section{CONCLUSIONS AND SUGGESTIONS}

\section{Conclusion}

Based on research result and discussion, the conclusions can be stated below.

1. The decentralization ratio has a significant effect on Human Development Index (HDI). Higher the decentralization ratio will increase the Human Development Index. The implementation of fiscal decentralization by District/City Governments in North Maluku Province can improve the community welfare as calculated by HDI.

2. The independence ratio has a significant effect on HDI. Higher the independence ratio will increase the HDI. The financial independence of District/City Government can increase the society welfare in North Maluku Province.

3. The effectiveness ratio has a significant effect on HDI. Higher effectiveness ratio will increase the HDI. The financial management of District/City Government has also been implemented effectively to improve the community welfare.

4. The decentralization, independence, and effectiveness ratios simultaneously affect on HDI in North Maluku Province with a contribution of $77.7 \%$ and remaining $22.3 \%$ HDI is affected by other factors.

\section{Suggestions}

Based on the study results, researchers can provide several suggestions below.

1. Local governments should increase the decentralization level by increasing the local revenue because it is a factor that can be controlled independently. Local governments should utilize all available resources. The Taliabu Islands government, has a very low decentralization level, it take lessons from other regions and implement them in their own areas.

2. Local governments should increase their local independence by managing the factors that can be controlled independently, namely increasing local revenue and reducing loans. Loans are indeed useful in regional development efforts, but there are obligations in future. The West Halmahera District Government and 
South Halmahera District Government have loan, they can focus more on managing local revenue collection, such as taxes on non-metallic minerals and rocks.

3. The local government should increase the effectiveness in achieving the target of local revenue set for regional financing. Local governments should set the targets based on potential, not just mathematical calculations.

4. Future research should add other research variables and expand the population and years of research to make complete research. Other research variables that can be used are poverty and unemployment. Some district/city governments can increase the Human Development Index, but cannot to suppress the existing poverty and unemployment levels.

\section{REFERENCES}

Afrimayosi. 2020. Tesis. Kinerja Keuangan daerah, Korupsi dan Kesejahteraan Masyarakat dalam Perspektif Teori Agensi.

Algifari. (2014). Hubungan Antara Pendapatan per Kapita dan Indeks Pembangunan Manusia (IPM). Yogyakarta: Sekolah Tinggi Ilmu Manajemen YKPN.

Amalia, F. R., \& Purbadharmaja, I. P. (2014). Pengaruh Kemandirian Keuangan Daerah dan Keserasian Alokasi Belanja Terhadap Indeks Pembangunan Manusia. Jurnal Ekonomi Pembangunan Universitas Udayana, Vol. 3, No. 6, Juni 2014: 257-264.

Apriana, Dina. dan Suryanto, Rudi., 2010, "Analisis Hubungan Antara Belanja Modal, Pendapatan Asli Daerah, Kemandirian Daerah dan Pertumbuhan Ekonomi Daerah (Studi pada Kabupaten dan Kota se Jawa-Bali)", Jurnal Akuntansi dan lnvestasi, Vol. XI No. 1, Januari.

Ardi. (2018). Analisis Kemandirian Keuangan Daerah. Inovasi. 13. 92. 10.29264/ jinv.v13i2.2461

Astuti, W. (2015). Analisis Pengaruh Kinerja Keuangan Terhadap Pertumbuhan Ekonomi dan Dampaknya terhadap Pengangguran dan Kemiskinan (Studi pada Kabupaten dan Kota di Pulau Jawa Periode 20072011). Jurnal EBBANK, $\quad 6(1), \quad 18$ http://www.ebbank.stiebbank.ac.id/index.php/EBBANK/article/view/61

Astuti, Y., Krisniawati, Zulkarnain, M., dan Maifizar, A. 2019. Pengukuran Kesejahteraan Masyarakat Melalui Kinerja Keuangan Daerah Terhadap Indeks Pembangunan Manusia Di Kabupaten Aceh Timur. Community: volume 5, nomor 2, Oktober 2019.

Bailusy, M. N. (2019). Kinerja Keuangan Daerah dan Indeks Pembangunan Manusia: mediasi pertumbuhan ekonomi. JEAMM, Volume 1, Nomor 1, Oktober 2019, Hal. 55-69.

Bastian, I. (2010). Akuntansi Sektor Publik Suatu Pengantar Edisi Ketiga. Jakarta: Erlangga.

Berliani, K. (2016). Pengaruh kinerja keuangan terhadap pertumbuhan ekonomi dan implikasinya terhadap kesejahteraan masyarakat Kabupaten Majalengka. Jurnal Indonesia Membangun, 15(2), 15-27.

Bharanti, Bonifasia Elita. 2019. The Effect Of Fiscal Balance Transfer, Financial Performance On Capital Expenditure Impacting On The Human Development Index Of Papua Province. Jurnal Kajian Ekonomi \& Keuangan Daerah, Volume 4, Nomor 3, Desember 2019: 157-183.

Bowo, R. M. P. A. (2014). Pengaruh Modal Sosial terhadap Kemiskinan Rumah Tangga. Jejak Journal of Economics and Policy, 7(2), 109-120. https://doi.org/10.15294/jejak.v7i1.3596

Buhr, N., Gray, R., \& Milne, M. J. (2014). Histories, rationales, voluntary standards and future prospects for sustainability reporting. Sustainability accounting and accountability, 51.

Cohen, J., \& Grifo, J. A. (2007). Multicentre trial of preimplantation genetic screening reported in the New England Journal of Medicine: an in-depth look at the findings. Reproductive biomedicine online, 15(4), 365-366.

Dewi, P.A.K, dan Sutrisna, I.K. 2014. Pengaruh Kemandirian Keuangan Daerah Dan Pertumbuhan Ekonomi Terhadap Indeks Pembangunan Manusia Di Provinsi Bali. E-Jurnal Ekonomi Pembangunan Universitas Udayana Vol. 4, No. 1, Januari 2014.

Donaldson, L., \& Davis, J.H. (1991.) Stewardship Theory or Agency Theory: CEO Governance and Shareholder Returns. Australian Journal of Management, 16(1), 49-65.

Dwiyandari, L.D.Y., dan Badera, I.D.N. 2018. Pengaruh Kinerja Keuangan pada Belanja Daerah dan Pertumbuhan Ekonomi dan Implikasinya pada Indeks Pembangunan Manusia. E-Jurnal Akuntansi Universitas Udayana, Vol.22.3. Maret (2018): 1741-1770.

Erwina, Wanda. 2020. Tesis. Pengaruh Kinerja Keuangan Daerah Terhadap Indeks Pembangunan Manusia, Tinkat Pengangguran Terbuka, dan Indeks Gini dengan Pertumbuhan Ekonomi, sebagai Variabel Intervening, dan Opini Laporan Keuangan Pemerintah Daerah sebagai Variabel Moderating di Indonesia.

Evlyn, M., dan Rahayu, Y. 2018. Pengaruh Kinerja Keuangan Pemerintah Daerah Terhadap Kesejahteraan Masyarakat Pada Kabupaten/Kota Di Provinsi Jawa Timur. Jurnal Ilmu dan Riset Akuntansi : Volume 7, Nomor 1, Januari 2018.

Ghozali, I. 2013. Aplikasi Analisis Multivariate dengan Program IBM SPSS 21 Update PLS Regresi. Semarang: 
Badan Penerbit Universitas Diponegoro.

Halim, A. (2007). Akuntansi Sektor Publik: Akuntansi Keuangan Daerah. Jakarta: Salemba Empat.

Hamid, Aceng Abdul. 2018. Analisis Pengaruh Kinerja Keuangan Daerah Terhadap Tingkat Kesejahteraan Masyarakat Kabupaten Majalengka - Jawa Barat. Jurnal Sekuritas. (Saham, Ekonomi, Keuangan dan Investasi ), Vol.1, No.4, Juni 2018, Halaman : 38 - 51.

Hamimah dan Zulkarnain. 2020. Pengaruh Kinerja Keuangan Daerah Terhadap IPM Kabupaten/Kota Di Jawa Barat. Riset Ekonomi, Akuntansi dan Perpajakan Vol 1 No. 2 September 2020.

Harliyani, E. M., \& Haryadi, H. (2016). Pengaruh Kinerja Keuangan Pemerintah Daerah Terhadap Indeks Pembangunan Manusia di Provinsi Jambi. Jurnal Perspektif Pembiayaan Dan Pembangunan Daerah, 3(3 SE-), 129-140. https://online-journal.unja.ac.id/JES/article/view/3514

Hood, C. (1995). The "new public management" in the 1980s: Variations on a theme. Accounting, organizations and society, 20(2-3), 93-109.

Irviani, R, dan Kasmi, C.J. 2017. Pengaruh Pendapatan Daerah Dan Kinerja Keuangan Terhadap Pertumbuhan Ekonomi Dan Kesejahteraan Masyarakat Pada Kabupaten/Kota Provinsi Lampung. Akuntabilitas: Jurnal Penelitian Dan Pengembangan Akuntansi, Vol. 11 No. 1 Januari 2017.

Iskandar. (2013). Metodelogi Penelitian Pendidikan dan Sosial (Kualitatif dan Kuantitatif). Jakarta: Gaung Persada Press.

Iskandar, A, dan Subekan A. 2017. Kinerja Keuangan Daerah Dan Kesejahteraan Rakyat Di Era Desentralisasi Fiskal (Studi Empiris Pada Kabupaten/Kota Provinsi Sulawesi Selatan TA 2008-2012). Jurnal Info Artha Sekolah Tinggi Akuntansi Negara (STAN) Vol.I/XII/2014 - ISSN 0852-6737 : 79-101.

Kasmir. 2015. Analisis Laporan Keuangan. Jakarta : PT Raja Grafindo Persada

Khairudin, Aminah, dan Redaputri, A.P. 2020. Pentingnya kinerja keuangan pemerintah daerah untuk meningkatkan kesejahteraan masyarakat di indonesia. Akuntabel 17 (1), 2020 148-151.

Krina.L.L. (2003) . Indikator Alat Ukur Prinsip Akuntabilitas, Transparansi Dan Partisipasi. Jakarta: Badan Perencanaan Pembangunan Nasional

Mahmudi. 2011. Akuntansi Sektor Publik. Yogyakarta: UII Press.

--------- (2010). Analisis Laporan Keuangan Pemerintah Daerah: Panduan Bagi Eksekutif, DPRD, dan Masyarakat dalam Pengambilan Keputusan Ekonomi, Sosial dan Politik. Yogyakarta: Unit Penerbitan Percetakan YKPN.

Mardiasmo. 2011. Otonomi dan Manajemen Keuangan Daerah. Andi: Yogyakarta

McKendrick, J. (2007). Modernization of the public accounting systems in central and eastern European countries: The case of Romania. International Public Management Review, 8(1), 168-185.

Minarti, S. 2011. Manajemen Berbasis Sekolah: Mengelola Lembaga Pendidikan Secara Mandiri. Ar-Ruzz Media: Jogjakarta

Mouw, E. (2013). Kualitas Pelayanan Publik di Daerah. Jurnal UNIERA, 92-103.

Munfarida, S., dan Priyojadmiko, E. 2020. Pengaruh Pendapatan Asli Daerah, Dana Alokasi Umum, Rasio Efektivitas dan Rasio Kemandirian Terhadap Indeks Pembangunan Manusia. AMAR (Andalas Management Review), Vol. 4, No. 2 (2020) 46-59.

Prasetyo. 2013. Fundamental Makro Ekonomi. Yogyakarta: Beta Offset.

Prasetyo, Wahyudi Eko. 2015. Tesis. Hubungan Kinerja Pengelolaan Keuangan Daerah Terhadap Tingkat Kesejahteraan Masyarakat Kabupaten Banyuwangi.

Putry, N.A.C, dan Badrudin, R. 2017. Pengaruh Kinerja Keuangan Daerah Terhadap Opini Audit dan Kesejahteraan Masyarakat di Daerah Istimewa Yogyakarta. JRMB, Volume 12, No. 1, Juni 2017.

Saiful. 2011. “Analisis Kinerja Keuangan Kabupaten Sukoharjo Tahun Anggaran 2006-2008.” Jurnal Akuntansi dan Keuangan, 1(1), 4-5.

Sari, F.N.G., dan Riharjo, I.B. 2020. Pengaruh Kinerja Keuangan Pemerintah Daerah Terhadap Indeks Pembangunan Manusia Pada Kabupaten Atau Kota Di Provinsi Jawa Timur. Jurnal Ilmu dan Riset Akuntansi : Volume 9, Nomor 8, Agustus 2020.

Sarjono. 2016. Hasil Audit, Jabatan Gubernur, Kinerja Keuangan Daerah Dan Dampaknya Terhadap Kesejahteraan Masyarakat. Jurnal Liquidity, Vol. 5, No. 1, Januari-Juni 2016, hlm. 43-52.

Setyowati, Lilis dan Suparwati, Yohana Kus. 2012. Pengaruh Pertumbuhan Ekonomi, DAU, DAK, PAD dengan Pengalokasian Anggaran Belanja Modal sebagai Variabel Intervening (Studi Empiri pada Pemerintah Kabupaten dan Kota se-Jawa Tengah). Jurnal Prestasi Vol. 9 No. 1

Shah, A and Thompson, T. 2002. Implementing Dezentralized Local Governance: A Teacherous Road with Potholes, Detours and Road Closures, Prepared for "Can Decentralization Help Rebuild Indonesia?" A Conference Sponsored by The International Studies Program, Andrew Young School of Policy Studies, Georgia State, University, Atlanta.

Sekaran. (2016). Martin Tuchman School of Management BS in Business Learning Objectives. Salemba Empat Jakarta. 
Sidik, F., \& Sidik, F. (2018). Kemiskinan Dan Pembangunan Sektor Pendidikan di Kabupaten Ngawi: Merumuskan Isu Strategis Poverty and Development of Education Sector in Ngawi District: Defining Strategic issues. 3(1), 1-13.

Sugiyono. 2012. Metode Penelitian Kuantitatif Kualitatif dan R\&D. Bandung: Alfabeta

Suryaningsih, N.Y., Utama, M.S., dan Yasa, I.N.M. 2015. Dampak Kinerja Keuangan Daerah Terhadap Kesejahteraan Masyarakat Kabupaten/Kota Di Provinsi Bali. E-Jurnal Ekonomi dan Bisnis Universitas Udayana 4.08 (2015) : 537-554.

Swandewi, Anak Agung Istri Agung. 2014. Pengaruh Dana Perimbangan Dan Kemandirian Keuangan Daerah Terhadap Keserasian Anggaran Dan Kesejahteraan Masyarakat Pada Kabupaten/Kota Di Provinsi Bali. EJurnal Ekonomi dan Bisnis Universitas Udayana 3.7 (2014) :356-376.

Syamsudin, Cahya, B. T., \& Dewi, S. N. (2015). Pengaruh kinerja keuangan terhadap pertumbuhan ekonomi, pengangguran dan kemiskinan. Daya Saing Jurnal Ekonomi Manajemen Sumber Daya, 17(1), 15-27.

Todaro. 2006. Pembangunan Ekonomi (edisi kesembilan, jilid I). Jakarta : Erlangga

UNDP. 1995. Human Development Report 1995. New York: Oxford University Press.

Ulum, I., \& Sofyani, H. (2016). Public (Sector) Accounting.

Yuana, A. 2014. Analisis Kinerja Keuangan Daerah Terhadap Pertumbuhan Ekonomi dan Ketimpangan Regional di Era Desentralisasi Fiskal (Studi Kabupaten/Kota di Provinsi Jawa Timur Periode 2008-2012). 